\title{
Pengaruh Diare Terhadap Malnutrisi pada Balita di Puskesmas Batoh Banda Aceh Tahun 2015
}

\author{
Mustaqiem Isda, Tristia Rinanda, ${ }^{* *}$ Rachmad Suhanda* \\ *Bagian Ilmu Kesehatan Masyarakat, **Bagian Mikrobiologi Fakultas Kedokteran Universitas Syiah Kuala
}

Latar belakang. Malnutrisi merupakan keadaan tubuh yang tidak mendapatkan asupan gizi yang cukup. Salah satu penyakit infeksi yang dapat menyebabkan malnutrisi adalah diare. Kejadian diare di Puskesmas Batoh merupakan angka tertinggi dari seluruh puskesmas yang ada di Kota Banda Aceh.

Tujuan. Mengetahui pengaruh diare terhadap malnutrisi dan Risiko Relatif (RR) diare pada Balita malnutrisi di Puskemas Batoh Kota Banda Aceh.

Metode. Pengambilan data dilakukan menggunakan data primer dari wawancara serta pengukuran status gizi dan data sekunder dari rekam medik dan Kartu Menuju Sehat (KMS).

Hasil. Jumlah subjek 42 Balita yang dibagi dalam 2 kategori, yaitu diare sering dan jarang. Karakteristik subjek digambarkan secara deskriptif. Data dianalisis dengan uji Chi-square. Total 42 Balita, 52,4\% adalah gizi kurang dan dengan uji Chi-square menunjukkan bahwa variabel independen (diare) berpengaruh terhadap malnutrisi $(\mathrm{p}<0,05)$. Risiko relatif $(\mathrm{RR})$ menunjukkan bahwa Balita dengan diare sering berisiko menjadi malnutrisi sebesar 10,00 kali.

Kesimpulan. Diare memiliki hubungan yang signifikan terhadap kejadian malnutrisi. Balita dengan diare sering memiliki risiko 10,00 kali untuk menjadi malnutrisi. Sari Pediatri 2016;18(1):50-4

Kata kunci : diare, malnutrisi, balita, Banda Aceh

\section{The Effect of Diarrhea on Infants with Malnutrition in Puskesmas Batoh Banda Aceh in 2015}

Mustaqiem Isda, ${ }^{*}$ Tristia Rinanda, ${ }^{*}$ Rachmad Suhanda*

Background. Malnutrition is a condition in which body is not supplied by a sufficient amount of nutrients. One of the gastrointestinal condition which leads to malnutrition is diarrhea. The incidence of diarrhea in Batoh Primary Health Care is the highest among the other Puskesmas (Community Health Centers) in Banda Aceh.

Objective. This research aimed to determine the effect of diarrhea towards malnutrition and Relative Risk (RR) of diarrhea in infants who develop malnutrition in Batoh Community Health Center, Banda Aceh.

Method. This study was a cohort retrospective research. The data was collected using primary data from interview and the measurements of nutritional status and also secondary data from the medical history records and Children's Health Card/Kartu Menuju Sehat (KMS). The number of subjects in this study was 42 infants, who were divided into two categories, namely regular diarrhea and rare diarrhea. The characteristics of subject were presented descriptively. The data from this study were analyzed by using Chi-Square test. Result and conclusion. Out of 42 infants, 22 (52,4\%) were undernourished and the Chi-Square test showed that diarrhea significantly affected the malnutrition condition $(\mathrm{p}<0.05)$. The Relative Risk (RR) showed that the risk of infants with regular diarrhea to develop malnutrition were 10.00 times. Sari Pediatri 2016;18(1):50-4

Keywords: diarrhea, malnutrition, infant, Banda Aceh

Alamat Korespondensi: Dr. Tristia Rinanda, M.Si. Fakultas Kedokteran Universitas Syiah Kuala. Jl. Tanoh Abee, Darussalam, Banda Aceh, 23111, Telp/ fax: (0651) 7551843. Email: tristia_rinanda@yahoo.com 
$\mathrm{M}$ alnutrisi merupakan penyebab utama kematian dan kecacatan fungsional pada Balita. Kematian Balita di dunia mencapai 9,7-10,6 juta jiwa per tahun, 53\% disebabkan oleh malnutrisi dan 18\% diakibatkan oleh diare. ${ }^{1}$

Gizi buruk masih menjadi masalah kesehatan di semua negara berkembang. Menurut World Health Organization (WHO), 175 juta anak mengalami malnutrisi berdasarkan data berat badan menurut umur dan sekitar 230 juta mengalami stunting dilihat dari tinggi badan menurut umur. Kematian anak dengan malnutrisi meningkat 5-20 kali dibandingkan dengan anak dengan nutrisi yang cukup. Dua pertiga kematian Balita disebabkan oleh malnutrisi langsung dan tidak langsung. ${ }^{2}$

Aceh termasuk ke dalam kategori kritis terkait masalah gizi. Aceh menduduki peringkat ketujuh dari seluruh provinsi di Indonesia yang mengalami masalah malnutrisi. Satu dari empat Balita di Aceh mengalami malnutrisi. Persentase Balita di Aceh yang mengalami malnutrisi 26,3\%. Persentase ini merupakan angka kritis yang ditetapkan oleh WHO tahun 2010, yaitu 20,0\% - 29,0\%. Pada tahun 2014 tercatat jumlah kasus gizi buruk di Aceh mencapai 341 kasus. ${ }^{3,4}$

Malnutrisi merupakan suatu komplikasi maupun faktor risiko dari penyakit diare. Malnutrisi dan diare memiliki hubungan dua arah. Diare dapat menyebabkan kekurangan gizi akibat dari penyerapan sari makanan yang berkurang. Diare yang berkepanjangan akan menimbulkan gangguan perkembangan dan pertumbuhan anak. ${ }^{5-7}$

Malnutrisi dapat terjadi akibat penyakit diare. Hal ini dapat menyebabkan pertumbuhan dan perkembangan anak yang tidak optimal hingga kematian. ${ }^{5}$ Insiden diare bervariasi menurut musim dan umur. Penyakit ini adalah penyebab kematian Balita nomor dua di dunia (16\%) setelah pneumonia (17\%). Hingga tahun 2010, kematian pada anak meningkat $40 \%$ akibat diare. ${ }^{3}$

\section{Metode}

Penelitian cohort retrospective dengan pengumpulan data riwayat diare dari rekam medis dan informasi ibu Balita di Puskesmas Batoh, Kota Banda Aceh. Data status nutrisi diambil dengan pengukuran antropometri berdasarkan kurva WHO dan indeks massa tubuh (IMT/U). Penelitian dilakukan selama kurun waktu Oktober 2015 sampai November 2015.

Sampel yang digunakan adalah pasien Balita Puskesmas Batoh yang sesuai dengan kriteria inklusi dan ekslusi. Kelompok dibagi berdasarkan diare sering dan diare jarang. Total jumlah sampel yang dibutuhkan adalah 40,8 Balita yang dibulatkan menjadi 41 Balita. Pada penelitian ini dibutuhkan dengan jumlah yang sama maka total sampel menjadi 42. Masing-masing kelompok terdiri atas 21 Balita.

Kriteria inklusi adalah Balita usia di bawah 5 tahun yang menetap di wilayah kerja Puskesmas Batoh dalam satu tahun terakhir. Data dibagi menjadi dua kategori, yaitu Balita dengan diare sering dan jarang. Pada penelitian dilakukan pencatatan usia, jenis kelamin, pendidikan ibu, dan jumlah anak dalam keluarga.

Data diolah dengan perangkat lunak statistik. Uji Chi-square digunakan untuk membandingkan antara kelompok diare sering dan jarang. Hasil dinyatakan bermakna secara statistik jika nilai $\mathrm{p}<0,05$.

\section{Hasil}

Karakteristik umum subjek penelitian yang diamati adalah pendidikan ibu, jumlah anak, umur Balita, dan jenis kelamin Balita (Tabel 1).

Tabel 1 menunjukkan responden dengan pendidikan ibu SMA 38,1\% diikuti dengan SMP $35,7 \%$. Responden dengan jumlah anak dalam keluarga 2 (dua) 38,1\% dan jumlah anak dalam keluarga 3 (tiga) 7,1\%. Responden Balita mayoritas berusia di atas 2 hingga 3 tahun (35,7\%). Mayoritas responden penelitian berjenis kelamin laki-laki $57,1 \%$ dan perempuan $42,9 \%$.

Sebaran subjek berdasarkan status nutrisi dan diare tertera pada Tabel 2 dan 3. Dari keseluruhan subjek penelitian, Balita dengan nutrisi normal 20 (47,6\%) Balita, sedangkan dengan gizi kurang $22(52,4 \%)$. Persentase Balita dengan gizi kurang lebih banyak dibandingkan dengan gizi normal. Balita dengan diare kategori sering $21(50 \%)$ Balita, sedangkan dengan riwayat diare kategori jarang 21 (50\%). Responden Balita dibagi menjadi 2 (dua) kategori masing-masing berjumlah 21 Balita.

Pada Tabel 4 terlihat adanya hubungan bermakna antara variabel bebas (diare) terhadap variabel terikat (malnutrisi), nilai $\mathrm{p}<0,05$. Pada pasien diare dengan kategori sering memiliki risiko relatif (RR) untuk 
Tabel 1. Karakteristik umum subjek penelitian

\begin{tabular}{lcc}
\hline Karakteristik & Frekuensi (n) & Persentase (\%) \\
\hline Pendidikan ibu & & \\
SD & 2 & 4,8 \\
SMP & 15 & 35,7 \\
SMA & 16 & 38,1 \\
D3 & 2 & 4,8 \\
S1 & 7 & 16,7 \\
Jumlah anak & & \\
1 & 8 & 19 \\
2 & 16 & 38,1 \\
3 & 9 & 21,4 \\
4 & 6 & 14,3 \\
5 & 3 & 7,1 \\
Usia balita (tahun) & & \\
$0-1$ & 8 & 19,0 \\
$>1-2$ & 8 & 19,0 \\
$>2-3$ & 15 & 35,7 \\
$>3-4$ & 8 & 19,0 \\
$>4-5$ & 3 & 7,1 \\
Jenis kelamin & & \\
Laki-laki & 24 & 57,1 \\
Perempuan & 18 & 42,9 \\
\hline
\end{tabular}

Tabel 2. Karakteristik subjek penelitian berdasarkan status nutrisi

\begin{tabular}{lcc}
\hline Karakteristik & Frekuensi (n) & Persentase $(\%)$ \\
\hline Nutrisi & & \\
Normal & 20 & 47,6 \\
Kurang & 22 & 52,4 \\
\hline
\end{tabular}

Tabel 3. Karakteristik subjek penelitian berdasarkan status diare

\begin{tabular}{lcc}
\hline Karakteristik & Frekuensi $(\mathrm{n})$ & Persentase $(\%)$ \\
\hline Diare & & \\
Sering & 21 & 50 \\
Jarang & 21 & 50 \\
\hline
\end{tabular}

masuk kategori malnutrisi (gizi kurang) 10,00 kali. Dengan demikian, diketahui bahwa terdapat hubungan yang bermakna antara diare dengan malnutrisi pada Balita di Puskesmas Batoh Banda Aceh. Balita yang menderita diare memiliki risiko 10 kali lebih besar untuk menjadi malnutrisi dibandingkan Balita yang tidak menderita diare.

\section{Pembahasan}

Diare dan malnutrisi mempunyai hubungan yang bermakna. Hal tersebut sesuai dengan laporan yang dibuat oleh International Center for Diarrheal Disease in Bangladesh bahwa diare dapat menyebabkan anakanak menjadi malnutrisi. ${ }^{10}$ Gupta $\mathrm{dkk}^{9}$ di India juga melaporkan bahwa terdapat risiko relatif (RR) 14,4 kali pada Balita yang sering diare untuk terjadinya malnutrisi. Guerrant $\mathrm{dkk}^{1}$ melaporkan malnutrisi disebabkan oleh peningkatan frekuensi serta durasi diare. Das dan Rahman ${ }^{10}$ juga melaporkan riwayat daire memiliki hubungan yang bermakna terhadap terjadinya malnutrisi dengan nilai $\mathrm{p}<0,05$.

Penelitian di Kenya juga melaporkan bahwa morbiditas diare dan kejadian malnutrisi memiliki kekuatan hubungan yang besar dengan koefesien korelasi (Rs) 0,8. Diare di Kenya tersebut terjadi akibat sumber air yang tersedia telah tercemar dengan limbah kakus. ${ }^{11}$

Diare dan malnutrisi memiliki hubungan dua arah. Diare mengakibatkan terjadinya malabsorpsi serta maldigesti yang dapat mengurangi asupan nutrisi yang diserap oleh tubuh. ${ }^{12}$ Diare akibat gangguan absorpsi terjadi saat volume cairan yang berada di kolon lebih besar dari kapasitas absorpsi. Kelainan pada usus halus mengakibatkan absorpsi menurun dan sekresi bertambah. Apabila fungsi usus halus normal, diare dapat terjadi akibat absorpsi di kolon menurun dan sekresi di kolon meningkat. ${ }^{3}$ Maldigesti terjadi akibat

Tabel 4. Hasil analisis hubungan diare dengan malnutrisi dengan uji Chi-square $(\mathrm{p}<0,05)$

\begin{tabular}{|c|c|c|c|c|c|c|c|c|}
\hline Karakteristik & & & utrisi & & To & & & RP \\
\hline Diare & Normal & $\%$ & Kurang & $\%$ & Jumlah & $\%$ & $\mathrm{P}$ & К \\
\hline Sering & 1 & 4,8 & 20 & 95,2 & 21 & 100 & 0,000 & 10,00 \\
\hline Jarang & 19 & 90,5 & 2 & 9,5 & 21 & 100 & & \\
\hline Total & 20 & 47,6 & 22 & 52,4 & 42 & 100 & & \\
\hline
\end{tabular}

Keterangan:, $\mathrm{RR}$ = relative risk 
kegagalan untuk mencerna makanan secara adekuat. Hal tersebut disebabkan oleh sekresi enzim pencernaan yang tidak memadai. ${ }^{13}$

Diare dapat juga dikaitkan dengan gangguan motilitas. Meskipun motilitas jarang menjadi penyebab utama malabsorbsi, perubahan motilitas mempunyai pengaruh terhadap absorpsi. Peningkatan ataupun penurunan motilitas, keduanya dapat menyebabkan diare. Penurunan motilitas dapat mengakibatkan bakteri tumbuh subur. Kegagalan motilitas usus yang berat menyebabkan statis intestinal yang dapat mengakibatkan terjadinya inflamasi. Patogen akan menginvasi usus sehingga akan berdampak pada sistem pertahanan mukosa usus. ${ }^{14}$ Infeksi pada usus dapat mengubah status nutrisi melalui penurunan asupan makanan dan absorpsi usus, peningkatan katabolisme, dan sekuesterasi nutrisi yang diperlukan untuk sintesa jaringan dan pertumbuhan. ${ }^{14}$

Infeksi saluran pencernaan dapat merusak mukosa serta vili usus yang akan menganggu penyerapan nutrisi. Sel-sel epitel usus halus yang rusak diganti oleh enterosit baru, berbentuk kuboid yang belum matang sehingga fungsinya belum baik. Villus mengalami atrofi dan tidak dapat mengabsorpsi cairan dan makanan dengan baik. ${ }^{3}$ Cairan dan makanan yang tidak terserap akan meningkatkan tekanan koloid osmotik usus dan terjadi hiperperistaltik usus sehingga cairan dan makanan tersebut terdorong keluar usus melalui anus, menimbulkan diare dari penyerapan air dan nutrien yang tidak sempurna. ${ }^{15}$

Bakteri patogen usus akan memengaruhi struktur dan fungsi tight junction. Tightjunction berfungsi untuk mencegah terjadinya kebocoran sel dan mencegah masuknya cairan ekstraselular ke dalam sel. Tight junction terbagi menjadi dua jenis, yaitu zonula ocludens dan fasia ocludens. Zonula ocludens terdapat pada selsel epitel usus halus yang sifatnya mengelilingi pinggir apikal sel-sel epitel tersebut. Zonula ocludens berfungsi sebagai penutup pada bagian apikal dari ruang intersel sehingga tidak dapat dilewati oleh molekul yang larut dalam air, merekatkan sel yang bersebelahan sehingga memungkinkan organ yang dibentuk oleh sel ini dapat meregang tanpa terjadi kerusakan sel, sebagai barier yang mencegah terjadinya difusi protein dari luar sel ke daerah baso lateral ruang intersel atau sebaliknya. ${ }^{16}$

Efek infeksi bakterial pada tight junction akan memengaruhi susunan anatomis dan fungsi absorpsi cytoskeleton dan perubahan susunan protein. Komponen protein dari tight junction meliputi protein integral membran, occludin, claudin, molekul adhesi dan tricellulin. ${ }^{16}$

Cytoskeleton berfungsi untuk memberikan kekuatan mekanik pada sel, menjadi kerangka sel, serta membantu gerakan substansi dari satu bagian sel ke bagian yang lain. Kedua komponen ini atau salah satunya dapat mengakibatkan hipersekresi klorida yang akan diikuti oleh natrium dan air. ${ }^{16}$ Gangguan absorpsi nutrisi akibat faktor tersebut menyebabkan asupan nutrisi berkurang. Gangguan pencernaan yang terjadi secara terus-menerus dapat mengakibatkan terjadinya malnutrisi.

\section{Kesimpulan}

Terdapat pengaruh diare terhadap kejadian malnutrisi pada Balita di Puskesmas Batoh tahun 2015. Balita dengan riwayat diare berisiko 10,00 kali untuk masuk ke dalam kriteria gizi kurang (malnutrisi).

\section{Daftar pustaka}

1. Guerrant RL, Oriá RB, Moore SR, Oriá MOB, Lima AAM. Malnutrition as an enteric infectious disease with long-term effects on child development. Nutr Rev 2008;66:487-505

2. Widoyono. Penyakit tropis : Epidemiologi, penularan, pencegahan, dan pemberantasannya. Jakarta: Penerbit Erlangga; 2011.h.197-8.

3. Juffrie M, Soenarto, Sri SY, Oswari H, Arief S, Rosalina I, dkk. Buku ajar gastroenterologi-hepatologi. Jakarta: Badan Penerbit IDAI; 2012.h.87-8

4. Kementerian Kesehatan Republik Indonesia. Profil kesehatan Indonesia tahun 2013. Jakarta: Kementerian Kesehatan Republik Indonesia; 2013.

5. Kliegman RM, Behrman RE. Nelson essentials of pediatrics. Edisi ke-2. Philadelphia: W. B. Saunders Company; 1994.h.87

6. Ahmed T. Global burden of maternal and child undernutrition and micronutrient deficiencies. Annals Nutrition and Metabolism 2013; suppl 1:8-17.

7. Kuntari T, Jamil NA, Sunarto, Kurniati O. Faktor risiko malnutrisi pada balita. Jurnal Kesehatan Masyarakat Nasional 2013;7:572-6.

8. Primayani D. Status gizi pada pasien diare akut di ruang 
rawat inap anak RSUD SoE, Kabupaten Timor Tengah Selatan, NTT. Sari Pediatri 2009;11:90-3.

9. Gupta A, Sarker G, Rout A, Mondal T, Pal R. Risk correlates of diarrhea in children under 5 years of age in slums of Bankura, West Bengal. J Global Infect Dis 2015;7:23-9.

10. Das S, Rahman R. Application of ordinal logistic regression analysis in determining risk factors of child malnutrition in Bangladesh. Nutr J 2011;10;124.

11. Njuguna J, Muruka C. Diarrhoea and malnutrition among children in a Kenyan District. J Rural Trop Pub Health 2011;10:35-8.

12. Checkley W, Buckley G, Robert HG. The childhood mlanutrition and infection network. Multi-country analysis of the effect of diarrhea on childhood stunting. IntJ Epidemiol 2008;4:816-30.
13. Marshall WJ, Bangert SK. Clinical Biochemistry Metabolic and Clinical Aspects. Edisi ke-2. USA: Elsevier; 2008.

14. Subagyo B, Santoso NB. Diare akut. Dalam: Buku Ajar Gastroenterologi-Hepatologi. Edisi ke-1. Jakarta: Badan penerbit UKK Gastroenterologi-Hepatologi IDAI. 2010. h.87-110.

15. Rodriguez L, Cervantes E, Ortiz R. Malnutrition and Gastrointestinal and Respiratory Infections in Children. Int J Enviroment Res Pub Health 2011;8: 1174-205.

16. Berkes J. Intestinal ephitel to enteric pathogens: effect on tight junction barrier, ion transport, and inflamation. GUT 2003;6:439-51.

17. Fanning A, Mitic L, Anderson JM. Transmembrane proteins in the tight junction barrier. J Am Soc Nephrol 1999;6:1337-45. 